\title{
Exercise is Medicine: Is there a Dose-response for Major Depression?
}

\section{Sergio Machado ${ }^{1,2 *}$}

${ }^{1}$ Laboratory of Physical Activity Neuroscience (LABNAF), Physical Activity Postgraduate Program, Salgado de Oliveira University, Niterói, Brazil ${ }^{2}$ Laboratory of Panic and Respiration, Institute of Psychiatry, Federal University of Rio de Janeiro, Rio de Janeiro, Brazil

\section{Editorial}

Major Depression (MD) is a common and disabling disease, affecting more than 100 million people worldwide [1], associated with impairments in patients' cognitive abilities, and reduced health and quality of life (QoL) [2]. The prevalence of depression is around $15 \%$ to $20 \%$, with females experiencing rates that are 1.5 to 3 times higher than those of males, with predominance on adolescence [3].

MD is usually treated with antidepressant medications and psychotherapy, but only $25 \%$ of the population has access to these types of intervention [4]. However, the rate of remission of patients undergoing antidepressant treatment is approximately $50 \%$, which encourages investment in alternative therapies $[5,6]$, such as aerobic exercise (AE).

AE is considered a relevant therapeutic option, available as a form of effective treatment in mild to moderate depression $[7,8]$, and its regular practice can bring physiological, psychological and social benefits to practitioners $[9,10]$. Studies show that $\mathrm{AE}$ is an important factor in the treatment of depression [11], providing positive physiological and psychological changes involved in mood enhancement.

$\mathrm{AE}$ contributes to autonomic balance and its effects can extend to improve mental health with reduction of symptoms $[8,12]$, of weight gain induced by antipsychotics [13], and of cardiovascular risk [14], and increase in cardiorespiratory fitness (APCR) [15]. However different methods and intensities may provide different psychological responses to exercise, interfering with adherence [16].

Regarding the AE methods, Ekkekakis [16] demonstrated that self-selected AE, i.e., when intensity is selected by the practitioner, can provide superior psychological responses compared to the imposed or prescribed exercise (i.e., externally defined intensity). Some authors have suggested that self-selected exercise is more effective in improving depressed mood and well-being when compared to exercise prescribed in a given intensity range $[17,18]$. Callaghan et al. [19] identified that 12 sessions of self-selected AE provided a superior effect in reducing depression compared to exercise at prescribed intensity. However, Knapen et al. [20] and Meyer et al. [21] have identified that selfselected $\mathrm{AE}$ does not generate superior effects in reducing depression. Nevertheless, Meyer et al. [21] demonstrated that self-selected AE, when compared to the prescribed exercise, provided a lower postexercise BDNF (brain-derived neurotrophic factor) plasmatic response.

In addition, high-intensity exercise has been shown to be effective in clinical populations [22]. In this sense, Jung et al. [23] reported that individual sessions of high intensity interval exercise resulted in a more positive affective response than continuous exercise at moderate or vigorous intensity. Nelson and Morgan [24] and Meyer et al. [25] did not find differences between self-selected AE performed in mild, moderate and high intensity on mood, well-being and depression.

In another experiment, Meyer et al. [21] examined the relationship between changes in serum total BDNF and acute post-exercise mood in depressed women and identified that the exercise led to improvement in depression irrespective of intensity, providing significant acute increases in BDNF serum levels, which were also not dependent on intensity. In addition, Bartholomew et al. [26] AE performed on treadmill with moderate intensity are sufficient to improve mood and well-being in depressed individuals. However, increased exercise intensity may lead to more vagal withdrawal, not being interesting in depressed patients with cardiovascular comorbidities. Therefore, findings seem to be inconsistent and do not allow establishing the appropriate dose-response. It is important to identify them so that professionals involved with the prescription can provide benefits with safety, aiming to increase the adherence of this population to regular physical exercises.

\section{References}

1. Hammar A, Ardal G (2009) Cognitive functioning in major depression--a summary. Front Hum Neurosci 3: 26.

2. Cooney GM, Dwan K, Greig CA, Lawlor DA, Rimer J, et al. (2013) Exercise for depression. Cochrane Database Syst Rev 9: CD004366.

3. Kessler RC, Berglund P, Demler O, Jin R, Merikangas KR, et al. (2005) Lifetime prevalence and age-of-onset distributions of DSM-IV disorders in the National Comorbidity Survey Replication. Arch Gen Psychiatr 62: 593-602.

4. Halliwell E (2005) Running for your life. Ment Health Today, pp: 25-27.

5. Machado M, Iskedjian M, Ruiz I, Einarson TR (2006) Remission, dropouts, and adverse drug reaction rates in major depressive disorder: a meta-analysis of head-to-head trials. Curr Med Res Opin 22: 1825-1837.

6. Thase ME, Haight BR, Richard N, Rockett CB, Mitton M, et al. (2005) Remission rates following antidepressant therapy with bupropion or selective serotonin reuptake inhibitors: A meta-analysis of original data from 7 randomized controlled trials. J Clin Psychiatr 66: 974-981.

7. Carek PJ, Laibstain SE, Carek SM (2011) Exercise for the treatment of depression and anxiety. Int J Psychiatr Med 41: 15-28.

8. de Souza Moura AM, Lamego MK, Paes F, Ferreira Rocha NB, SimoesSilva V, et al. (2015) Comparison among aerobic exercise and other types of interventions to treat depression: A systematic review. CNS Neurol Disord Drug Targets 14: 1171-1183.

9. Blumenthal JA, Babyak MA, Doraiswamy PM, Watkins L, Hoffman BM, et al (2007) Exercise and pharmacotherapy in the treatment of major depressive disorder. Psychosomatic Med 69: 587-596.

10. Eyre $\mathrm{H}$, Baune BT (2012) Neuro-immunological effects of physical exercise in depression. Brain, Behavior, and Immunity 26: 251-266.

11. Mota-Pereira J, Silverio J, Carvalho S, Ribeiro JC, Fonte D, et al. (2011) Moderate exercise improves depression parameters in treatment-resistant patients with major depressive disorder. J Psychiatr Res 45: 1005-1011.

12. Silveira H, Moraes H, Oliveira N, Coutinho ES, Laks J, et al. (2013) Physical

${ }^{*}$ Corresponding author: Sergio Machado, Laboratory of Panic and Respiration Institute of Psychiatry, Federal University of Rio de Janeiro, Rio de Janeiro, Brazil Tel: (21) 21384964; E-mail: secm80@gmail.com.

Received: November 03, 2018; Accepted: November 04, 2017; Published: November 14, 2017

Citation: Machado S (2018) Exercise is Medicine: Is there a Dose-response for Major Depression?. J Psychiatry 21: e112. doi:10.4172/2378-5756.1000e112

Copyright: @ 2018 Machado S. This is an open-access article distributed unde the terms of the Creative Commons Attribution License, which permits unrestricted use, distribution, and reproduction in any medium, provided the original author and source are credited 
Citation: Machado S (2018) Exercise is Medicine: Is there a Dose-response for Major Depression?. J Psychiatry 21: e112. doi:10.4172/2378$5756.1000 \mathrm{e} 112$

exercise and clinically depressed patients: a systematic review and metaanalysis. Neuropsychobiology 67: 61-68.

13. Curtis J, Watkins A, Rosenbaum S, Teasdale S, Kalucy M, et al. (2016) Evaluating an individualized lifestyle and life skills intervention to prevent antipsychotic-induced weight gain in first-episode psychosis. Early Interv Psychiatry 10: 26776

14. Bartels SJ, Pratt SI, Aschbrenner KA, Barre LK, Jue K, et al. (2013) Clinically significant improved fitness and weight loss among overweight persons with serious mental illness. Psychiatr Serv 64: 729-736.

15. Stubbs B, Rosenbaum S, Vancampfort D, Ward PB, Schuch FB (2016) Exercise improves cardiorespiratory fitness in people with depression: A meta-analysis of randomized control trials. J Affect Disord 190: 249-253.

16. Ekkekakis P (2009) Let them roam free? Physiological and psychological evidence for the potential of self-selected exercise intensity in public health. Sports Med 39: 857-888

17. Scully D, Kremer J, Meade MM, Graham R, Dudgeon K (1998) Physica exercise and psychological well-being: a critical review. Br J Sports Med 32 111-120.

18. Ryan RM, Deci EL (2006) Self-regulation and the problem of human autonomy: does psychology need choice, self-determination, and will? J Personal 74 1557-1585.

19. Callaghan P, Khalil E, Morres I, Carter T (2011) Pragmatic randomized controlled trial of preferred intensity exercise in women living with depression. BMC Public Health 11: 465
20. Knapen J, Sommerijns E, Vancampfort D, Sienaert P, Pieters G, et al. (2009) State anxiety and subjective well-being responses to acute bouts of aerobic exercise in patients with depressive and anxiety disorders. Br J Sports Med 43: 756-759.

21. Meyer JD, Koltyn KF, Stegner AJ, Kim JS, Cook DB (2016) Relationships between serum BDNF and the antidepressant effect of acute exercise in depressed women. Psychoneuroendocrinol 74: 286-294.

22. Shiraev T, Barclay G (2012) Evidence based exercise - clinical benefits of high intensity interval training. Aust Fam Physician 41: 960-962.

23. Jung ME, Bourne JE, Little JP (2014) Where does HIT fit? An examination of the affective response to high-intensity intervals in comparison to continuous moderate- and continuous vigorous-intensity exercise in the exercise intensityaffect continuum. Plos One 9: e114541.

24. Nelson TF, Morgan WP (1994) Acute effects of exercise on mood in depressed female students. Med Sci Sports Exerc 26: S156.

25. Meyer JD, Koltyn KF, Stegner AJ, Kim JS, Cook DB (2016) Influence of Exercise Intensity for Improving Depressed Mood in Depression: A Dose-Response Study. Behav Ther 47: 527-537.

26. Bartholomew JB, Morrison D, Ciccolo JT (2005) Effects of acute exercise on mood and well-being in patients with major depressive disorder. Med Sci Sports Exerc 37: 2032-2037. 